\title{
Does Foreign Capital Crowd-Out Domestic Saving in Developing Countries? An Empirical Investigation of Ghana
}

\author{
Barnabas Nartey Angmortey ${ }^{1} \&$ Patrick Tandoh-Offin ${ }^{2}$ \\ ${ }^{1}$ GIMPA Business School, Ghana Institute of Management and Public Administration, Achimota, Accra, Ghana \\ ${ }^{2}$ GIMPA School of Public Service and Governance, Ghana Institute of Management and Public Administration, \\ Achimota, Accra, Ghana \\ Correspondence: Barnabas Nartey Angmortey, Ghana Institute of Management and Public Administration, \\ GIMPA Business School, P. O. Box AH-50, Achimota, Accra, Ghana. Tel: 233-245-355-012. E-mail: \\ bangnortey@yahoo.com
}

Received: April 1, 2014

Accepted: May 22, 2014

Online Published: July 25, 2014

doi:10.5539/ijef.v6n8p161

URL: http://dx.doi.org/10.5539/ijef.v6n8p161

\begin{abstract}
Savings in Ghana like most developing countries is very low. This poses problems to investment spending and accelerated economic growth due to lack of capital formation. The trend has been to use foreign capital as the source of development. This work tries to examine the contribution that foreign capital has had on the Ghanaian economy. Precisely, the work examines the effect of foreign capital on domestic savings. More precisely, it examines the effect of foreign direct investment, foreign aids and grants and foreign commercial borrowing on domestic savings. The study uses the co-integration technique for the estimation of the long-run and the Error Correction Model (ECM) to estimate the short-run dynamic savings model in Ghana.

The outcome of the study shows that there is a positive and significant effect of foreign capital on real domestic savings in Ghana in the long run, though not steady but volatile. The short-run dynamic model revealed that foreign capital has no significant effect on real domestic savings in Ghana in the short-run. The three components of foreign capital do not therefore displace domestic savings both in the short-run and the long-run. The policy implications are that, Ghana must rely more on foreign direct investment by improving on the locational advantages. Again, the capital market must be strengthened to provide an avenue for investing the profits of firms to prevent capital flight.
\end{abstract}

Keywords: foreign direct investment, foreign aids, foreign commercial borrowing and co-integration

\section{Background to the Study}

Theoretically, savings is the traditional source for investment (fund) and therefore, a determinant of fixed capital formation and economic growth. To accelerate the rate of fixed capital formation through investment, domestic savings mobilization needs to be increased far above the percent levels. The low level of savings in Ghana like most developing countries, had led to the dependence on external or foreign capital to complement internal revenue for economic development. Aryeetey and Harrigan (2000) noted that much of the investment financing in Ghana since the financial sectors reforms in 1986 came from foreign sources.

\subsection{Statement of the Problem and the Justification of the Study}

The investment led growth hypothesis holds that capital inflows increase domestic investments, and increased investments contribute to the achievement of higher growth (Baharumshah \& Thanoon, 2000). Higher growth invites more investment and more investments attract further capital flows. This virtuous cycle of capital inflows and economic growth were indeed an integral part of what was known as the Asian 'miracle' (Baharumshah \& Thanoon, 2001). Ghana, like other developing countries of East Asia and Latin America, has the characteristic of large current account deficit, which contributes to the large inflow of foreign capital. The imperative of capital inflows into developing countries is seen to ameliorate external constraints facing such countries.

But, what has been the implication of such a massive inflow of external capital into developing countries like Ghana, which is constantly grappled with macroeconomic imbalance? Developing economies such as Ghana have generally tended to encounter numerous problems such as shortage of exchange reserves, exchange rate appreciation (Fernandez-Arias \& Hausman, 1995), excessive money supply and the consequent pressure on prices, 
higher consumption and lower savings. The option to increase capital formation through domestic sources raises a policy dilemma. Increase in domestic investment demands that enough funds must be available in the financial market from which firms can obtain credits or loans. This calls for increase in domestic savings. To achieve high domestic savings real deposit interest rate must be positive and high enough to motivate people to save in financial forms. The negative effect of real deposit interest, to induce, is high lending rate that investors who sources for funds from the banks to invest are charged. This has the tendency to slow down the level of investment and eventually it inhabits the capital accumulation needed for rapid economic growth.

To circumvent this dilemma most developing countries, including Ghana rely on the inflow of foreign capital as an alternative source of funds to promote investment and capital formation. The result is that interest rates, both real deposit and lending rates are low. More critical real deposit rates are negative due to persistently high inflation rates and the interest rate spread is very large. Under these conditions potential domestic savers are prevented from participating in the financial market whereby inflow of foreign capital instead of complementing domestic savings rather tends to crowd out savings. The level to which this exits in Ghana needs to be investigated for the correct policy instrument to be put in place to make sure that inflow of foreign capital does not crowd out domestic savings.

The specific objective of the study is to identify (what has been) the effect of foreign capital inflow on domestic savings in Ghana.The subsequent aim is to decompose the foreign capital into its component-foreign direct investment (FDI), grants and aids (GA) and foreign commercial borrowing (FCB) to see their individual effects on domestic savings in Ghana. This constitutes an important gap in that no study exits on the study of foreign capital at the disaggregation level and more so little evidence also exit on the study of the direct impact of foreign capital savings in Ghana.

The study is organised into four sections. Section one present the background, problem statement and justification of the study. Theoretical survey is covered in section two. The methodology, presentation and discussion of the result are covered in section three. The conclusion constitutes the last section.

\section{Theoretical Literature Review}

\subsection{Foreign Capital Inflow and Domestic Savings}

The debate over the increase in capital inflow into developing countries and its implications for domestic savings has resumed with renewal interest in the 1990s as capital mobility has become significant. The Asian financial crises due to the withdrawal of capital flow or foreign savings have reminded us of the risk of flows capital (Reisen and Soto (2000).There is now a large literature on the role of foreign capital (or aid) in determining the host country's economic growth and savings. Consensus on whether foreign capital inflow is directly or inversely related to domestic savings has been eludingthe academic community.

Several theories have been used to establish the link between foreign capital inflow and domestic saving. Theory shows that the impact of foreign capital inflows and domestic savings is ambiguous and complex (Feldstein, 2000).

Rahman (1968) proposed the psychological hypothesis to explain the relationship between capital flows and savings. He argued that an increase in foreign funds causes a relaxation of government savings and thus, a reduction in average savings rate. Chenery and Eckstein (1968) suggested the foreign exchange constraint hypothesis in accessing the relationship between foreign capital and national savings. They hypothesized on the two-gap model of economic growth. An increase in exports is accompanied by a rise in savings ratio since it permits a larger volume of investment.

Also, inflow of foreign capital provides a change for additional investment but at the same time serves as a one to one substitute for domestic savings in financing investment. While both increase in exports and capital imports provide the foreign exchange needed to support a higher level of investment, the increase in capital imports also increases the current account deficit. Hence, gross domestic savings as measured does not rise through gross domestic investment but would increase by the amount of capital flow. Summers (2000) maintains that "enormous social benefits" are made possible by the efficiency gains from the reallocation of capital from industrial to developing countries.

The reallocation can improve living standards by mobilizing global savings to finance investment, growth and savings in countries where the marginal productivity of investment is relatively high. Foreign capital flows may be associated with increased efficiency of production and thus with higher growth rate and consequently domestic savings. Increase in productivity increases in productivity through the transmission of ideas across national borders offset an apparently costless way for developing countries to catch up, generating, according to one scholar, 
an "advantage of backwards linkages (Gerschenkron 1952 in Global Development Finance).Abramowitze (1986) in the GDF (2001) highlighted the importance of "social capability" for the ability to exploit the potential created by the international gap in ideas. Thus, the potential for productivity growth depends on domestic capability required for absorption of the transfer technologies.

\subsubsection{Foreign Direct Investment and Domestic Savings}

Haavelmo (1963) put forward the opinion that there is an inverse relationship between FDI flow and the saving rate of the country. FDI inflow provides additional resources in the sense that it slackens the pressure put by development programme for a saving rate as high as possible. Over time, the private savings effect of FDI is given by the increase in income imputable to the FDI through the mps. With regards to public savings, the effect of FDI is as a result of the difference between tax revenue from FDI and government expenditure on FDI (Boss, Sanders, $\&$ Secchi, 1968).They further maintained that FDI could have effect on domestic savings cumulatively through its effects on private and government savings. The cumulative effect on private savings is directly related to income through the mps. The cumulative effect on public savings is given by the direct effect trace to FDI plus the indirect effect on indirect taxation on taxes on profits, on taxes on wages and taxes on imports attributed to FDI.

The marginal effect of FDI looks at the change that FDI makes on the current year over the previous year. The marginal effect on private savings once more is directly related to the marginal income effect. The marginal effect on public savings is given by three additive terms. These are the direct taxes effect of FDI, the increase in taxes profit and wages, indirect taxes on imports, and increase in public expenditure indirectly related to FDI. Mishra, Mody and Murhiod (2000) argue that when a country is poor and saves little, additional FDI from outside the country can help realize its investment opportunities to generate more savings through employment, output and income.

\subsubsection{Aids and Grants and Domestic Savings}

Taslim and Weliwita (2000) traced the theoretical relationship between foreign aids and domestic savings to both the vicious circle of poverty theory and the two-gap theory by Chenery and Strout (1966). The vicious circle of poverty theory holds that, poverty is both a cause and consequences of poverty. Poor countries with limited capital stock can save little, as their incomes are barely enough to ensure subsistence needs. Low savings imply a low level of capital accumulation in these countries.This in turn implies that productivity stagnates at low level such that income remains low. They are, therefore trapped in a vicious circle of poverty that can be broken only by exogenous interventions. When aids are channeled into such a country it could raise incomes above subsistence. The initial savings could increase investment, which would in turn generate further savings in the aid recipient country.

The two-gap theory states that investment effort in poor countries in the early stages of development is limited by two constraints. First, these countries may be unable, perhaps due to poverty, to save sufficiently from current income to provide investment needed to achieve a target rate of growth. Second, investment (and output) could also be limited by the unavailability of sufficient amounts of imported inputs due to a balance of payment constraint. The paucity of both savings and foreign exchange (to pay for imported materials) could be overcome by an inflow of foreign aids. By providing additional resources, aid would also rise as the realized incremental investment raises domestic output through higher productive capacity as well as the multiplier effect in the case of underutilized capacity. This was, and continues to be, one of the most forceful arguments in favor of foreign aid to developing countries.

\subsubsection{Foreign Borrowing and Domestic Savings}

If access to foreign borrowing at international interest rates is unlimited foreign borrowing fills the gap between domestic investment and national savings. In this case, foreign borrowing is simply the result of national savings decision and not one of its determinants. Schmidt-Hebble, Serven and Solimano (1996) note, however, that if foreign borrowing is rationed either by the leaders or by government regulation in developing countries, the domestic savers and investors are constraint in their intertemporal choices by the amount of available finance and foreign borrowing becomes a determinant of savings.

Economic theory suggests that private capital will move from countries where it is abundant to countries where it is scarce because the returns on new investments are higher where capital is limited. Such a reallocation of capital will boast investment and savings in the recipient country and as Summers (2000) suggests, brings enormous social benefits. Underlying this theory is the premise that returns on capital decrease as more machinery is installed and new structures are built due to increase in savings, which are reinvested in the domestic economy. 


\subsection{Empirical Literature Review}

\subsubsection{Foreign Direct Investment and Domestic Savings}

The empirical evidence on the causal relationship among domestic saving and FDI flows is rather inconclusive.

Edwards (1996) highlighted the importance of FDI as one of the explanatory variables in savings equation. Specifically, he concluded that high FDI is associated with lower domestic savings. De Mello (1999) argued that in an open economy FDI might be detrimental to growth if it is a substitute for domestic savings, in which case, FDI inflows exacerbate balanced of payment problems via foreign exchange remittances. Similarly, the work by Rienhart and Talvi (1998) based on data from 24 countries in Latin America and Asia found a negative correlation between foreign capital and domestic savings for most of the countries in the sample. This point is also made by Nurhan (1999), where she showed that a surge in capital inflows adversely affected domestic savings by increasing current consumption and current account deficit.

FDI contributes positively to savings ratios in the short-run as well as in the long run. Hence, suggesting that a transitory or permanent change in FDI would augment the supply of domestic savings (Baharumshuh \& Thanoon, 2000). Over (1975) reported a positive link between FDI and national savings. Besides that, he went on to note that an increase in FDI provided an equal boost to savings rate and was a stimulus to economic growth. Based on a large data set, Gruben and Mclead (1998) using data from 18 Asian and Latin America countries showed that an increase in the share of FDI to GDP is positively and significantly related to domestic savings. When absorptive capacity is high, FDI does have the expected positive relationship with productivity and saving. For Taiwan, China, Chang and Lin (1999) in GDF (2001) found that FDI has been associated with higher productivity and saving in foreign owned firms and with a spillover to domestically owned firms. A 1 percent increase FDI in an industrial sector is associated with an increase in the productivity of domestic firms and increase in domestic savings in the sector of 1.40 to 1.88 percent

The work of Agosin and Mayer (2000), emphasizes the inconclusive empirical effect of FDI on economic growth and saving in developing countries. Three countries in Africa, including Ghana and three countries in Asia showed a crowding - in effect of FDI on saving. Four countries in Africa and five in Asia showed a crowding-out effect. The effect is neutral in five countries, seven countries and five countries from Africa, Latin America and Asia respectively. Arndt, Buch and Scnitzer (2008) studied FDI and domestic investment(saving)at the industry level using a panel cointegration method and found evidence for a positive long run impact of FDI on the domestic capital formation. Osinubi and Amaghionyeodiwe (2010) found positive impact of foreign private investment on economic growth and for that matter saving in Nigeria. The work of Muhammed, Fatima and Omade (2011) concluded that inflow of FDI from South Africa and Ghana has positive impact on economic growth in Nigeria. Nosheen (2013) reports a long run positive influence on growth and by implication saving in Pakistan.

Most studies of FDI on Ghana have not concentrated on the direct relationship between FDI and saving but mostly the impact of FDI on growth. Again in the Ghana situation the result is mixed. Gaypong and Karikari (1999), Abenser (2004), Frimpong and Oteng-Abayia (2008) on GDP and growth of GDP all recorded positive impact of FDI. Also indicating positive effect are works by Abor et al. (2008) on exports, Adanutsi (2008) on industrial output, Adams and Twenibua (2000) on stock market capitalization, Abor(2010) on firm productivity, Adennyi et al. (2011) on agricultural growth, Djokoto (2010a) on daily protein and energy consumption and Agbola(2013) economic growth as well as Nkechi (2013), Insah (2013) and Antwi et al. (2013). The studies by Karkari (1992) on GDP, Djokoto (2011) on agriculture growth and Djokoto (2012b) however reported negative inpact of FDI.

\subsubsection{Aids and Grants and Domestic Savings}

A few economists have suggested that foreign aid is likely to retard development, a position taken in an article by Griffen and Enos (1970). Fry (1978) found the effect of foreign assistance on domestic savings to be negative and statistically significant. Boone (1996) using a cross-section data saw no relation between aid flows and either the domestic saving rate or economic growth. This result is consistent with earlier, less econometrically sophisticated empirical results in Mostly, Hudson and Horrell (1987), Griffen (1970) and Weisskopf (1972), all of which found little impact of aid on growth, capital accumulation and for that matter saving. Further, Boone (1996) finds that the coefficient on aid flows in a reduced form equation for investment over GDP is zero and for consumption over GDP is one, suggesting that aid flows go entirely into consumption. Once more, these results are confirmed by earlier, empirical results of Griffen (1970) and Mosley, Hudson and Horrell (1987).

Works by some other researchers record a positive correlation between foreign aids and domestic savings Papnek (1973), Dowling \& Hiememz, (1982), Gupta and Islam (1983) and Mosley, Hudson and Horrell (1987).These were all based on cross section data. This is supported by a later work of Boone (1995) for 14 poorest countries. 
Burnside and Dollar (1997) found that even though aid flows in general are not correlated with growth and savings aid flows to countries with sound macroeconomic policies do have a positive effect.Nurhan (1999) and others focus on a subset of more successful adjustment programs in sub-Saharan Africa and conclude that large increases in foreign aid did not appear to have led to a decline in domestic savings rates.

The World Bank, which also adopted an approach of dividing sub-Saharan Africa into groups characterised by their adjustment performance during 1987-1991, found that although part of foreign savings financed consumption, domestic savings rates in the better performing countries improved during the period. Duc (2006) made a cross country empirical study of aid and economic growth in developing countries using data from 1975 to 2000 and found evidence that foreign aid significantly and negatively correlates with growth. For inland countries as well as South Asian countries during the period of 1992-2000 is found to have a positive impact on growth. An empirical analysis of short run and long run impacts of aid on domestic saving in Nigeria by Eregha and Irughe (2009), the study revealed that short run and the long run foreign aid inflows have positive effects on domestic savings.

However, total debt service payment has negative impact on domestic savings. Testing the impact of foreign aid on domestic private investment in west Africa, Uneze's (2010), results show that multilateral aid affects private investment and for that matter saving positively but not bilateral aid, and aid uncertainty, defined by the coefficient of variation has a negative impact on private investment and therefore reduces the impact of aid on domestic private investment (saving) Shields (2013) examined the relationship between foreign aid and saving in119 countries and concluded that aid is directly related to saving, even though few countries show support for the crowding out hypothesis. Basnet (2013) examined the relationship on foreign aid, domestic savings and economic growth in South Asia using simultaneous equation system. The result indicated that aid has positive and significant effect on the growth rates of five nations studied during 1960 to 2008. However, foreign aid appeared to crowd out domestic savings rather done complementing it.

Aid can cause saving through growth in Real GDP. This required growth in GDP means that aid, especially technical assistance and nonfinancial will work when it responds to genuine demand and is well managed. Unfortunately a lot of technical assistance has not followed that concept. This has caused great loss since technical assistance has accounted for a large share of aid to developing countries. Tsikata (2001). Mosley, Hudson and Horrell (1987) also concede that there is no statistically significant correlation between foreign aid on the other hand and economic growth and savings on the other. Hasan's (2002) study of concessional foreign capital (aid) inflows and domestic savings across countries noted a mixed result on the direction and causality between aid and saving. Majority of the countries show casual independence but had little evidence to confirm either Griffn's dependence hypothsis or Papaneck's reverse causality hypothesis.Moreira(2005) evaluating the impact of foreign aids on economic growth in cross country study found that aid has less effect on growth in the short-run than in the long-run.

Studies on foreign aid on the economy of Ghana follow the path of FDI. Little direct study of the impact of foreign aids on savings exits. Arhenful (2005) concluded that foreign inflows lead to the depreciation of the cedi, implying that "The Dutch Disease" hypothesis of large foreign aid inflows is rejected in the case of Ghana. Tuffour (2013) in a study on foreign aid, domestic revenue and economic growth in Ghana reported a positive link from both domestic revenue and foreign aid to economic growth.

\subsubsection{Foreign Commercial Borrowing and Domestic Saving}

Commercial borrowing is generally found to have a significant influence on domestic investment and saving with the relationship being strongest for private international lending and weaker for portfolio (Boscorth \& Collins, 1999). Gupta (1987) on the other hand found a positive coefficient of foreign borrowing which are significant for Latin America but negative for Asia. Fry (1978) find the effect of foreign borrowing on domestic saving to be significant and negative, although its size was small.

With a foreign borrowing on domestic savings, although the secondary effects on capacity growth tend to increase savings. He found coefficients of foreign borrowing to be mixed signs and significant. Laudau (1969) again regressed saving on net capital inflow and gross national product found that 16 of the 18 countries tested, the partial derivative of savingwith respect to aid was significantly negative, with a range of $-0,2$ to- 0.9 . Chenery and Eckstein (1968) added the ratio of import to national income. For most of the countries the coefficient of foreign import was negative. Sigh (1971) investigated the relationship between an increase in the ratio of net flow to gross national product or net foreign capital to gross savings. He found both correlations to be negative. Sigh (1971) also concluded that foreign borrowing is a substitute for domestic saving. 


\section{Methodology}

\subsection{Specification of Model}

The model for the research is adopted from the model developed by Mahua and Sakthivel (2000). The model is an Error Correction one and estimates domestic savings directly. The original model (equation) is produced in equation 1 below:

$$
S_{t}=a_{0}+a_{1} F G_{t}+a_{2} F G_{t-1}+a_{3} G D P_{t}+a_{4} G D C F_{t}+U_{t}
$$

Where $\mathrm{S}_{\mathrm{t}}=$ the gross domestic savings in the current period, $\mathrm{FG}_{\mathrm{t}}=$ the foreign capital in the current period measured as Net Capital Account or Net Capital Investment, $\mathrm{GDP}_{\mathrm{t}}=$ gross domestic product at market price in the current year, $\mathrm{FG}_{\mathrm{t}-1}=$ foreign capital in the previous year and $\mathrm{GDCF}_{\mathrm{t}}=$ gross domestic capital formation. As per the model, we hypothesize that savings in the current period responds to foreign capital in the present period $(\mathrm{t})$ and the immediate past period ( $\mathrm{t}-1)$ with the overall output of the economy and investment.

We define the equation using the various type of foreign savings as separate variable in equation 2 below:

$$
L R G D S_{t}=f\left(L R G D P t, L R F B_{t}, L R F A_{t}, L R G D I_{t}\right)
$$

The specific form of the long-run equation is stated in equation 3

$$
L R G D S_{t}=a_{0}+a_{1} L R G D P_{t}+a_{2} L R F B_{t}+a_{3} L R F A_{t}+a_{4} L R F D I_{t}+U_{t}
$$

The shrot-run dynamic equation is in equation 4 below

$$
\begin{aligned}
& L R G D S_{t}=b_{0}+b_{1} \Delta L R G D P_{t-1}+b_{2} \Delta L R F B_{t-1}+b 4 \Delta L R F A_{t-1}+b_{4} \Delta L R F D I_{t-1}+b_{5}\left[L R G D S _ { t } \left(b_{0}\right.\right. \\
& \left.\left.+b_{1} L R G D P_{t}+b_{2} L R F B t+b_{3} L R F A_{t}+b_{4} L R F I_{t}\right)\right]_{-1}+U_{t}
\end{aligned}
$$

In the models, LRGDSt is the log of real gross domestic savings in the current period; LRGDPt is the log of real gross domestic product in the current period; LRFBt is the log of real foreign borrowing in the current period; LRFAt is the log of real foreign direct investment in the current year. The variables with the subcsipt $t-1$ are the respective previous year value. The term in the bracket capture the divergence from the long run equation equilibrium which captures the rate of adjustment (error correction term).

Both the theoretical and the empirical literature show that the effect of foreign capital on domestic savings is inconclusive. The original model is modified, by using the various types of foreign capital as separate independent variables. The study adopted this modification to bring out the specific effects of each of the constituents of foreign capital on domestic savings.

The choices of the ECM approach helps to analyze both the short-run and long-run effects of foreign savings on domestic savings. The economics model is modified to analyze the effect of the different types of foreign capital on real gross domestic savings in Ghana. The real gross domestic product is included in the model to allow us to compare the influences of real foreign savings on real gross domestic product on real gross domestic savings to effect of real foreign savings on gross domestic savings, where in this study is total of private and public savings.

\subsection{Data Sources}

Variables used in the study include real gross domestic savings (GDS) defined as the sum of private savings and public savings.Private savings include total savings deposits of private individuals.Real Gross domestic capital formation (GDI) is independent variable which is net fixed capital investments. Another independent variable is real gross domestic product (GDP) at market price which measures the production or output level in the country.Foreign capital (FC), defined here as either net capital account or net foreign investment which is the sum of foreign direct investment (FDI), foreign aid / grants (FA) as well as borrowing by private firms from foreign commercial banks (FCB)In short foreign capitals(savings) is the flow of savings of other countries which flow into another country (Boyes \& Melvin, 1990).A log transformation of all these variables were undertaken in order to standardize the variables. The values were normally in the nominal form and were converted into real value by deflating with CPI.

The data used in the study are quarterly data.The data covers the period of $1983 \mathrm{Q}_{1}$ to $2012 \mathrm{Q}_{4}$. This period was chosen due to the fact that it covers the most difficult years of the economic history of Ghana, that is, the reform and post-reform eras as well as the period of democratic governance.The data for the variable are obtained from various issues of International Financial Statistics Year Book; the Bank of Ghana quarterly bulletin and annual budget reports of many years and the yearly review of the Ghana economy by Institute of Social Statistics and Economic Research (ISSER) of the University of Ghana and Center for Policy Analysis (CPA). 


\subsection{Econometric Method and Estimation Techniques}

\subsubsection{Results of the Stationary Test}

The Augmented Dicky Fuller test results are presented in Table 1 It shows test of the variables at their levels. The results in Table 1 show that the hypothesis of unit root can be rejected, both at the $1 \%$ and $5 \%$ critical value with reference to real foreign borrowing (LRFB). This is due to the fact that t-value is greater (in absolute term) than the critical values. From the table, real foreign aids and grants (LRFA); real gross domestic product (LRGDP); real gross domestic savings (LRGDS) are all significant at their levels. This is based on the fact that their t-values are less (in absolute term) than the critical value. We therefore conclude that these four variables are non-stationary at their levels.

Table 1. Unit Root test for variable at their levels

\begin{tabular}{rll}
\cline { 2 - 3 } Variable & t-ADF & Lag length \\
\cline { 2 - 4 } LRFA & -1.19417 & 1 \\
LRFB & $-3.369139 *$ & 1 \\
LRFDI & -1.934287 & 1 \\
LRGDP & -1.546399 & 1 \\
LRGDS & -2.581815 & 1 \\
Note. Critical value at $5 \%$ & -2.8986 and at $1 \%=-3.5753 . *$ Indicate significance at 1\%.** Indicate significance at 5\%.
\end{tabular}

Since some (four) of the variables are not significant at their levels leading to non-rejection of the hypothesis of unit root, we went through differentiating them once if they could be made stationary. That is whether the hypothesis of unit root could be rejected. The test shows that the hypothesis of unit root can be rejected since the $\mathrm{t}$-values are greater (in absolute terms) than the critical values. We can therefore conclude from Table 2 that the four variables are I (1).

Table 2. Unit root test for the variables at their first difference

\begin{tabular}{llll}
\hline Variable & t-ADF & Lag-length & Order of Integration \\
\hline LRFA & $-5.164096^{* *}$ & 1 & -1 \\
LRFDI & $-8.819803^{* *}$ & 1 & -1 \\
LRGDP & $-8.171718^{* *}$ & 1 & -1 \\
LRGDS & $-7.380410^{* *}$ & 1 & -1 \\
\hline
\end{tabular}

Note. Critical Value at $5 \%=-3.5164$ and $1 \%=-2.8991 . *$ Indicate significance at $1 \% . * *$ Indicate significance at $5 \%$.

\subsubsection{Results of the Co-Integration Test}

The residual-base approach was used to test for cointegration in the regression. This involved checking the stationarity of the saved residual from the cointegration regression. The cointegration test result is recorded in Table 3. From Table 3 the cointegration results give the t-ADF value up to 1 lag which is significant at both $1 \%$ and $5 \%$. We can therefore conclude that the variables are really cointegrated at the level.

Table 3. Results of the cointegration test

\begin{tabular}{rlll}
\cline { 2 - 3 } & Variable & t-ADF & Lag length \\
\cline { 2 - 3 } Residual & $-4.979770 * *$ & 1 \\
\hline Note. Critical value at $5 \%$ & $=-2.8986$ and $1 \%$ & $-3.5153 . *$ & Indicate significance at $1 \% . * *$ \\
\end{tabular}

\subsection{Discussion of Results}

\subsubsection{Estimated Results for Long-Run Real Gross Domestic Savings Function}

The OLS result in Table 4 indicates that the explanatory power is very strong. The adjusted R2 is 0.928731 implies that the explanatory variables accounts for about $93 \%$ in the variations in the level of the real gross domestic savings in Ghana. All these are significant; this is confirmed by their t-ratios. The Durbin-Watson statistic of 
1.789754 indicates an absence of autocorrelation and the F-statistic 244.3373 with a probability of $100 \%$ implying that all the variables are jointly significant in explaining variation in private gross domestic savings in Ghana.

Table 4. Long-run regression results of the co-integration model

\begin{tabular}{llll}
\hline Variable & Coefficient & t-statistic & Probability \\
\hline LRGDP & 0.260257 & 3.441298 & 0.0009 \\
LRFA & 0.05606 & 3.705729 & 0.0004 \\
LRFB & 0.061232 & 3.067959 & 0.063 \\
LRFDI & 0.129546 & 8.548389 & 0 \\
C & -10.32255 & -10.21557 & 0 \\
\hline
\end{tabular}

Note. R-Squared: 0.928731; Adjusted R-squared: 0.924930;

F-statistic: 224.3373; Prob (F-statistic): 0.000016;

Durbin-Waston stat. 1.789754; ADF (1): -4.979970;

Critical value at $1 \%=-3.5153$ and $5 \%=-2 . .8986$.

Analysis of the Long-run results shows the estimated parameters for RGDP, FFA, RFB and RFDI as 0.260257 , $0.056060,0.061232$ and 0.129546 respectively. This means that on the average in the long-run $100 \%$ rise in RGDP, RFA, RFB, and RFDI increase real gross domestic savings by $26 \%, 5.6 \%, 6.0 \%$ and $12.9 \%$ respectively. The Coefficients of the components of foreign capital rejects the notion that foreign capital crowds out domestic savings in Ghana. This seems to support the findings of Gockel (2000) that much of savings in Ghana during the study period has been greatly due to the inflow of foreign capital. A critical comparison of the coefficients of the components of foreign capital reveals that FDI has the greatest effects on real domestic savings. On the average a $100 \%$ increase in RFDI increases real domestic savings by $13 \%$ with RFA and RFB increasing gross domestic savings by $5.6 \%$ and $6 \%$ respectively for every $100 \%$ increase.

\subsubsection{Estimated Result for Short-Run Error Correction Model}

The result from the residual-based approach gives strong evidence that the variables are indeed co integrated, thus justifying the adoption of error correction model. This involves the inclusion of the lagged residuals obtained from the long-run regression. The error correction term in short-run estimation of real gross domestic saving model is obtained from the general error correction model. This was done by eliminating the variables that had low t-values. The variables with t-values have high t-probability values. The final real gross domestic savings parsimonious model is presented in Table 5 .

Table 5. Results of the parsimonious short-run real gross domestic savings model by ordinary least square (OLS).

\begin{tabular}{lllll}
\hline Variable & Coefficient & Std & t-value & t-prob. \\
\hline Constant & -6.8972 & 0.340082 & -20.261 & 0.0154 \\
$\Delta$ LRGDS(-1) & 0.0973 & 0.070585 & 15.546 & 0.007 \\
$\Delta$ LRGDP(-1) & 0.049576 & 0.038086 & 1.302 & 0,0473 \\
$\Delta$ LRFB(-1) & -0.016876 & 0.018834 & -0.896 & 0.0333 \\
$\Delta$ LRFA(-1) & -0.014545 & 0.013413 & -1.084 & 0.0019 \\
$\Delta$ LRFDI(-1) & -0.012269 & 0.01394 & -0.88 & 0.0068 \\
ECM-1 & -0.37091 & 0.11103 & -3.341 & 0.001 \\
$R^{\wedge} 2=0.953751$ & RSS $=1.3205$ & DW $=-1.77$ & & \\
\hline
\end{tabular}

Note. Diagnostic Test:

\footnotetext{
AR 1-5 F $(5,65)=14.664(0.000)$;

ARCH $4 \mathrm{~F}(4,62)=1.9278(0.0070)$;

Normality Chi^2 (2) = $9.0104(0.0111)$;

$\operatorname{RESET} F(1,69)=1.6632(0.2015)$.
}

The result showed again that the explanatory variables explain the level of real gross domestic savings in Ghana in 
the short-run. The adjusted R squared value is 0.953751 , indicating that about $95.38 \%$ of the variation in real domestic savings in Ghana in the short-run is determined by the explanatory variables. The reported Durbin-Watson of 1.77 is approximately 2, suggesting the absence of autocorrelation. A serious study of the diagnostic tests both the general and parsimonious short-run real gross domestic savings results show they have passed all the tests. This indicates that we have no problem of autocorrelation (the AR test), autoregressive-conditioned heteroscedasticity (ARCH test), normality Chi-squared test and the model specification (RESET) tests as depicted by their insignificant test probability.

Analysis of the Short-Run dynamic (Error Correction Mechanism) model shows coefficients of the RFDI, RFA and RFB are all negative contrary to the results obtained on the long-run implying that all the components of foreign capital crowds out saving in Ghana in the short-run. However, a critical look at the t-values of RFA, RFA and RFDI are given as $-0.896,-1.084$ and -0.880 respectively. These values are nowhere near the value of two (2). The value implies that there is no statistically significant relationship between RFB, RFA and RFDI and domestic savings. We therefore conclude that RFB, RFA and RFDI do not influence domestic savings in the short-run. The short-run adjustments are made to correct any disequilibrium in the long run real domestic savings. The coefficient of the disequilibrium error which captures the disequilibrium of the OLS equation, explains the short-run dynamics and value of -0.37091 implies that around $37 \%$ of any disequilibria between the actual and equilibrium real gross domestic savings in one period is made up within the next period.

\section{Conclusion}

No evidence exists that increase in foreign capital as a whole crowded-out domestic savings in the long run but in the short-run as indicated by the coefficient of the components of foreign savings. In the short-run, however, all the coefficients indicate that foreign capital has no significant impact on domestic savings in the short-run. We also find that foreign capital, especially, FDI is positively related to savings not in the short-run but only in the long run. The implication is that transitory (or permanent) change in FDI augments the supply of domestic savings. FDI inflows permit the level of investment in a country to exceed the level of savings in the long run (Baharumshah \& Thanoon, 2000).

Following the results of the study the following policy issues are put forward. The governments of developing countries like Ghana needs to negotiate with the donor community to allow a certain proportion of the aids / grants to be directed into critical growth areas such as agriculture, industry in the form of the supply of inputs. The results show that commercial borrowing has relatively low impacts on domestic savings in the long run and no significant impact in the short-run. The policy issue here is that whilst Ghana must depend more on long-term loan there is the need to be selective. Of the three major components of foreign capital, foreign direct investment (FDI) is the most important, hence government of Ghana need to intensify inflow of FDIs.

\section{References}

Abor, J. (2010). Foreign direct investment and firm productivity: Evidence from firm-level data. Global Business and Economic Review, 12(4), 267-285. http://dx.doi.org/10.1504/GBER.2010.036055

Abor, J., Adjasi, C. K. D., \& Hayford, M. C. (2008). Foreign direct investmens affect the export decisions of firms in Ghana. African Development Review, 20(3), 446-465. http://dx.doi.org/10.1111/j.1467-8268.2008.00193.x

Abramouritze, A. (1986). International Capital Flows and Economic Growth. Global Development Finance.

Adams, A. M., \& Tweneboah, G. (2009). Foreign direct investment and stock market development: Ghana's evidence. International Research Journal of Finance and Economics, 26, 178-185.

Adeniyi, O., Omisakin, O., Egwaikehide, F. O., \& Onyinlola, A. (2012). Foreign direct investment, economic growth and financial sector development in small open developing economies. Economic Analysis and Policy, 42(1), 105-127.

Adenutsi, D. E. (2008). Effect of trade openness and foreign direct investment on industrial performance in Ghana. Journal of Business Research, 2(1\&2), 71-89.

Agbola, F. W. (2013). Does human capital constrain the impact of foreign direct investment and remittances on economic growth in Ghana? Applied Economics, 45(23), 2853-2862. http://dx.doi.org/10.1080/00036846.2012.676735

Ahmad, M. H., \& Ahmed, Q. M. (2000). Foreign Capital inflow and Domestic Saving in Pakistan: Cointergration Techniques and Error Correction Modelling. The Pakistan Development Review, 41(4), 825836. 
Antwi, S., Mills, E. F. E. A., Mills, G. A., \& Zahao, X. (2013). Impact of foreign direct investment on economic growth: Empirical evidence from Ghana. International Journal of Academic Research in Accounting, Finance and Management Sciences, 3(5), 18-25.

Arbenser, L. (2004). A general equilibrium analysis of inward flow of FDI in Ghana. The role of complementary policy. Working paper 69/2004. Humboldt University Berlin, Department of Agricultural economics.

Arhenful, P. (2013). The effect if foreign aid on exchange rate in Ghana. Advances in Management \& Applied Economics, 3(5), 151-169.

Aryeetey, E., \& Harrigan, J. (2000). Macroeconomic and Sectorial Development since 1970. In Aryeetey, E., Harrigan, J., \& Nissanke, M. (Eds.), Economic Reforms in Ghana. The Miracle or Mirage. Oxford: James Currey Ltd.

Baharumshah, A. Z., \& Thanoon, H. (2000). Foreign Capital, Savings and Economic Growth: A dynamic Panel Study on the East Asian Countries. Department of Economics. University of Putra. Malaysia.

Basnet, H. C. (2013). Foreign aid, domestic savings, and economic growth in South Asia. International Business \& Economic Research Journal, 12(11), 1389-1393.

Boone, P. (1996). Politics and the Effectiveness of Foreign Aids. European Economic Review, 40(11), 289-329. http://dx.doi.org/10.1016/0014-2921(95)00127-1

Boss, H. C., Sanders, M., \& Secchi, C. (1968). Private Foreign Investment in Developing Countries: A quantitative study on the evaluation of the Macro-Economic Effects. International Studies in Economics and Econometrics, 7.

Bosworth, B. P., \& Collins, S. M., \& Reinhert. (1999). Capital Flows to Developing Economies: Implication for Savings and Investment. Brookings Paperson Economic Activity, 143-180. http://dx.doi.org/10.2307/2534664

Burnside, A., \& Dollar, D. (1997). Aid, Policies and Growth. World Bank Policy Research Department. Washington DC.

Chan, Y., \& Lin, C. (1999). Foreign Direct Investment and Productivity: Evidence from selected Countries. In Building Coalitions for Effective Development Finance. Global Development Finance.

Chenery, H. B., \& Eckstein, T. (1968). Development Alternatives for Latin America. Journal of Political Econ., 78, 966-1006.

Chenery, H. B., \& Strout, A. M. (1966). Foreign Assistance and Economic Development. American Economic Review, 56, 679-693. http://dx.doi.org/10.1086/259685

De Mello, L. (1999). Foreign Direct Investment: Growth Evidence from Time Series and Panel Data. Oxford Economic Papers, 51(1), 133-152. http://dx.doi.org/10.1093/oep/51.1.133

Djokoto, J. G. (2011). Inward foreign direct investment flows grow security, and agriculture in Ghana: A granger causal analysis. International Journal of Economics and Finance, 3(6), 188-197. http://dx.doi.org/10.5539/ijef.v3n6p188

Djokoto, J. G. (2012a). Effect of foreign direct investment inflows into agriculture for food security in Ghana. Journal of Economics and Sustainable Development, 3(2), 81-92.

Djokoto, J. G. (2012b). Does causal relationship exist between external trade and foreign direct investment flow to agriculture in Ghana in Ghana? International Journal of Business and Management, (7), 179-193.

Duc, V. M. (2006). Foreign Aid and Economic Growth in developing countries: Across-Country Empirical Analysis.

Eregha, P. B., \& Irughe, I. R. (2009). An empirical analysis-run impacts of aid on domestic saving $i$ of the short-run and long in Nigeria. Journal of Economic Theory, 3(3), 53-56.

Feldstein, M. (2000). Aspects of Global Economic Integration: Outlook for the future. NBER (Working Paper. No.7899. National Bureau of Economic Research. Cambridge University Press. Baltimore.

Frempong, J. M., \& Oteng-Abayie, E. F. (2008). Bivariate causality analysis between FDI inflow and economic Growth in Ghana. International Research Journal of Finance and Economics, 15, 103-112.

Gerschenkron, J. (1952). International Capital Flows and Economic Growth: Capital inflows and Domestic investment and Savings. In Building Coalitions for Effective Development Finance. Global Development 
Finance.

Gockel, A. F., Harrington, R., \& Brownbridge, M. (2000). Saving and Investment. In Aryeetey, G. K. B. (Ed.), Foreign Capital, Domestic Savings and Economic Development (Vol. 32, pp. 99-122). Bulletin of the Oxford University Institute of Economics and Statistics.

Griffen, K. B., \& Enos, J. L. (1970). Foreign Assistance, Objectives and Consequences. Economic Development and Cultural Change, 18, 313-327. http://dx.doi.org/10.1086/450435

Gruben, W. C., \& Mclead, D. (1998). Capital Flows, Savings and Growth in the 1990s. Quarterly Review of Economics and Finance, 3(38), 287-301. http://dx.doi.org/10.1016/S1062-9769(99)80119-7

Gupta, K. L. (1970). Personal Saving in Developing Nations: Further Evidence. Review of Economics and Statistics, 46(1), 33-50.

Gupta, K. L., \& Islam, K. (1983). Foreign Capital and Domestic Savings: A Test of Haavelmo's Hypothesis with Cross Sectional Data: A comment. Review of Economics and Statistics, 52, 214-216. http://dx.doi.org/10.2307/1926125

Gyapong, A. O., \& Karikari, J. A. (1999). Direct Foreign Investment Strategies and Economic Performance in Ghana and Ivory Coast. Journal of Economic Development, 24(1), 133-147.

Haavelmo, T. (1963). The Econometric Approach to Development Planning. North Holland Publishing Company. Holland.

Hasan, M. S. (2002). Concessional foreign capital inflows and domestic savings across countires: Dependency hypothesis re-visited. Journal of Economic Studies, 29(6), 388-422. http://dx.doi.org/10.1108/01443580210448844

Hausmann, R., \& Fernandez-Arias, E. (2000). Foreign Direct Investment: Good Cholesterol? Inter-American Development Bank, Working Paper. No. 47. Washington.

Insah, B. (2013). Foreign Direct Investment Inflows and Economic Growth in Ghana. International Journal of Economic Practices and Theories, 3(2).

Karikari, J. A. (1992). Causality between direct foreign investment and economic output in Ghana. Journal of Economic Development, 17(1), 7-17.

Karikari, J. A. (1992). Causality between direct investment and economic output in Ghana. Journal of Economic Development, 17(1), 7-17.

Landau, L. (1969). Brazilian Saving: A note (Report No. 137). Project for Quantitative Research in Economic Development. Harvard University.

Mahua, R., \& Sakthivel, E. (2000). Has Foreign Savings 'Crowded-out’Domestic Savings in India? An Empirical Investigation. Institute of Economic Growth. University of Delhi Enclave, North Campus. Delhi.

Mody, A., Murshid, A. P., \& Mishra, P. (2000). Private Capital Flows and Growth. Finance and Development, 28(2).

Moreira, S. B. (2005). Evaluating the impact of foreign aid on economic growth: A cross-country study. Journal of Economic Development, 30(2), 25-48.

Mosley, P., Hudson, J., \& Horrell, S. (1987). Aid, the Public Sector, and the Market in Less Development Countries. Economic Journal, 97, 616-641. http://dx.doi.org/10.2307/2232927

Njoupouognigni, M., \& Ndambendia, H. (2010). Foreign Aid, Foreign Direct Investment and Economic Growth in Sub-Saharan Africa: Evidence from Pooled Mean Group Estimator (PMG). International Journal of Economics and Fianace, 2(3).

Nkechi, O. A. (2013). An econometric analysis of the impact of Foreign Direct Invest on economic growth of Ghana: The Role of Human Capital Development. International Journal of Humanities and Social Science Intervention, 2(8), 12-20.

Nosheen, M. (2013). Impact of Foreign Direct Investment on Gross Domestic Product. World Applied Sciences Journal, 24(10), 1358-1361.

Nurhan, Y. (1999). Short-Term Capital Inflows and Their Impact on Macroeconomic Structure: Turkey in the 1990s. The Developing Economies, 37(1), 89-113.

Osinubi, T. S., \& Amaghionyeodiwe, L. A. (2010). Foreign Private Investment and economic growth in Nigeria. 
Review of Economics and Business Studies, 3(1), 105-127.

Over, L. B. (1975). How Does Foreign Entry Affect the Domestic Banking Market? In Clasessens, E. T., \& Jansen, M. (Eds.), In Building Coalition for Effective Development Finance. The World Bank.

Papanek, G. (1973). Aid, Foreign Private Investment and Growth in Less Developed Countries. Journal of Political Economics, 81, 120-130. http://dx.doi.org/10.1086/260009

Rahaman, M. A. (1968). Foreign Capital and Domestic Savings. A Test of Haavelmo's Hypothesis with CrossCountry Data. Review of Economic Statistics, 50(February), 137-138. http://dx.doi.org/10.2307/1927068

Reinhart, C. M., \& Talvil, E. (1998). Capital Flows and Saving in Latin America and Asia: A Reinterpretation. Journal of Development Economics, 57, 45-66. http://dx.doi.org/10.1016/S0304-3878(98)00077-7

Reisen, H., \& Soto, M. (2000). The Poor Countries' International Financial Transactions. In Financing the Poorest Countries. The World Bank.

Schmidt, H. K., Seven, L., \& Solimano, A. (1996). Saving and Investment Paradigms, Puzzles and Policies. The World Bank Research Observer, 11.

Shields, M. P. (2014). Foreign aid and domestic saving: the crowding out effect. Discussion paper 35/07. Department of Economics. School of Business and Economics. Monash University.

Sigh, H. (1971). The Poor Countries' International Financial Transactions. Global Development Finance.

Summer, L. (2000). International Financial Crises: Causes, Prevention and Cures. American Economic Review, Papers and Readings, 90, 1-16. http://dx.doi.org/10.1257/aer.90.2.1

Taslim, J. T., \& Weliwita, R. (2000). Foreign Direct Investment and Productivity: Evidence from Selected Countries. In Building Coalitions for Effective Development Finance. Global Development Finance.

Tsikata, Y. M. R. (2001). Aids and Reforms in Africa. The World Bank Washington DC, USA.

Tuffour, J. K. (2013). Foreign aid, Domestic Revenue and Economic Growth in Ghana. Journal of Economics and Sustainable Development, 4(8), 125-33.

Uneze, E. (2010). Testing the impact of foreign aid on domestic private investment in West Africa. African Review of Money, Finance and Banking, 7-27.

Weisskopf, G. (1972). Flow of Foreign Capital in Bangladesh. Global Development Finance.

World Bank. (1999). Global Development Finance. Washington DC: World Bank.

\section{Copyrights}

Copyright for this article is retained by the author(s), with first publication rights granted to the journal.

This is an open-access article distributed under the terms and conditions of the Creative Commons Attribution license (http://creativecommons.org/licenses/by/3.0/). 